Vaginal Cytological Findings during Pregnancy in the Mothers of Three Anencephalic Babies

\begin{tabular}{|c|c|c|c|c|c|}
\hline Case No. & E.I. & K.I. & $\begin{array}{c}\text { Vaginal } \\
\text { Flora }\end{array}$ & Clumping & $\begin{array}{c}\text { Other } \\
\text { Features }\end{array}$ \\
\hline 1 & $\begin{array}{c}\text { Just above } \\
\text { normal }\end{array}$ & High & Variable & Variable & $\begin{array}{c}\text { Occasional } \\
\text { parabasal }\end{array}$ \\
\hline 2 & $\begin{array}{c}\text { Just above } \\
\text { normal }\end{array}$ & High & Variable & $\begin{array}{l}\text { Moderate to } \\
\text { good }\end{array}$ & $\begin{array}{l}\text { Occasional } \\
\text { parabasal }\end{array}$ \\
\hline 3 & $\begin{array}{c}\text { Variable; } \\
\text { mainly } \\
\text { normal }\end{array}$ & $\begin{array}{l}\text { Variable but } \\
\text { high (up to } \\
40 \% \text { ) in 3rd } \\
\text { trimester }\end{array}$ & Variable & Variable & Nil \\
\hline
\end{tabular}

E.I. = eosinophilic index
K.I. = karyopyknotic index

was having difficulties in acoepting the diagnosis, and karyotyping of mother and baby was deferred. MacNaughton ${ }^{8}$ reviewed the evidence that mothers of such babies may in the non-pregnant state have an abnormal steroid metabolism. An increased output of dehydroepiandrosterone has been reported in young mothers of mongoloid children ${ }^{10}$ but this has been questioned by others ${ }^{11}$ who discount the possibility that the differenoes present are due to translocations being present in only some of the mothers while others have a normal karyotype. However, the opportunity to study the hormonal status during pregnancy in such a condition does not often arise, and further studies may well indicate that some of the gene loci involved in regulating oestrogen metabolism during pregnancy reside in the affected chromosomes.

The presence of non-specific, unexplained, persistently abnormal hormonal cytological patterns in pregnancy in groups at risk may alert the clinician to the possibility of certain congenital defects being present and indicate the necessity for further investigations.

I would like to acknowledge the encouragement of Professors W. I. C. Morris and F. A. Langle and a research grant from the United Manchester Hospital.

-I am, etc.

D. K. SEN

Department of Obstetrics and Gynaecology,

University Hospital

Kuala Lumpur, Malaysia

Wachtel, E., in Modern Trends in Obstetrics, 4 ed. R. J. Kellar. London, Butterworths,

3 de Neef, J. C., Clinical Endocrine Cytology. New York, Harper and Row, 1965.

Sen, D. K., Ph.D. Thesis, Manchester University, 1969.

Sen, D. K., and Langley, F. A., Acta Cytologica,

1972, 16, 116. $1963,2,713$.

Frandsen, V. A., and Stakemann, G., Acta Entocrinologica, 1964, 47, 265.

MacNaughton, M. C., American fournal of o

$1959,31,523$.
10 Rundle, A., Coppen, A., and Cowie, V., Lancet, $1961,2,846$.

I1 Stern, M. I., Cowie, V. A., and Coppen, A.
Acta Endocrinologica, 1966, 53, 79.

\section{Can I Have an Ambulance, Doctor?}

SIR,-The article by Dr. T. C. Beer and others (9 February, p. 226) provides some very disturbing facts, not so much about the use of the ambulance service but about physiotherapy. What it reveals is that a treatment centre attached to one of the most modern hospitals in the country pro vides such a low level of treatment that the author's comments about the effectiveness of outpatient physiotherapy are almost bound to be correct. The last sentence is really the important one: "Doctors ordering [physiotherapy] should remember that it may be merely a potentially socially disruptive placebo."

The facts revealed in the article showed that $75 \%$ of the patients treated were receiving no more than one hour of physiotherapy per week. I find it incredible, at a time when rehabilitation services are being reassessed and recommendations made about the implementation of the Tunbridge Committee report and when consultants in rehabilitation are being appointed, that such a very low level of treatment with a modern rehabilitation centre which treats patients on a full-time basis-that is, the patients attend for a 37-hour working week and treatment is devoted to active exercise or effective forms of physiotherapy and recovery time is reduced to an absolute minimum thereby.

I wonder if this article is in fact illuscause, if it is, no wonder the rehabilitation services are in such urgent need of reappraisal and reorganization.-I am, etc.,

Medical Rehabilitation Centre,

D. E. FORD London N.W.1

\section{Cot Deaths}

SIR,-With reference to your very informative leading article ( 2 March, p. 341) the following factors seem always to be present when cot deaths occur: (1) horizontal position; (2) bed rest; (3) quiet sleep for some hours; (4) the baby is clothed and the covers are wrapped round the child; (5) a helpless and somewhat weak child; (6) an unsuspected and silent event; and (7) a greater or lesser degree of interstitial oedema in the lungs. ${ }^{1}$

The most reasonable pathogenesis for cot deaths according to these premises is, I think, that the baby is drowned in its own body fluid. This body fluid is more abundant in newborn babies and highly mobile. Interstitial oedema in the lungs hampers oxygen transport through the respiratory membrane, especially in the hypostatic parts of the lungs. The hypoxaemia which follows produces drowsiness, insensibility, and death.

If this theory is right the fatal event should never occur when: (a) the child is out of bed; (b) the baby is crying, when the oedema would be driven out of the chest; (c) the child is naked-heavy covers in the winter season, constricting clothes, and bulky nappies under the buttocks would tend to drive more blood into the thoracic cavity; (d) the child sleeps with the upper trating a norm for patient after-care be- half of the body elevated; $(e)$ the child has strength enough to get out of the flat, recumbent position; and $(f)$ there has been insufficient time since washing and feeding for enough oedematous fluid to gather.

In 1969 I was telephoned by a distressed mother who had just found her 31-day-old infant motionless and apparently dead. I immediately ordered the child to be placed in a vertical position. When I saw her some 6-7 minutes later breathing was present but hardly audible. The whole body was very pale, with some traces of scum around the mouth. The head and the limbs were quite flaccid. In the next 30 minutes recovery was very rapid. The baby became normal, yawned healthily, and wanted food. ${ }^{2}$ The girl has been in good health since then but somehow weaker than the two older children, who were twins.

Other potentially fatal diseases in which fluctuations in body fluid may be of decisive importanoe are croup ${ }^{3-5}$ (acute laryngitis) and pulmonary oedema due to heart failure. At necropsy the disastrous oedema may well be gone-as is the rule in dead bodies-into the common pool of hypostatic fluid.-I am, etc.,

Bærum, Norway

TORGILS AANELAND

1 Kerenyi, N. A., and Fekete, J. F., Canadian Aaneland, T., Tidsskrift for den Norske Laegeforening, 1970, 90, 1906

Aaneland, T., British Medical fournal, 1961, 1 1320.

Aaneland, T., Tidsskrift for den Norske Laegeforening, 1965, 85, 542 . forening, 1965, 85, 542. for den Norske Laege-
forening, 1965, 85, 1757.

\section{High-dose Frusemide in Renal Failure}

SIR,-With reference to the paper by Professor F. Cantarovich and others (24 November 1973 , p. 449) and the subsequent letter from Dr. D. Ganeval and his colleagues (9 February, p. 244) I should like to report my experience of the use of highdose frusemide in the treatment of acute tubular necrosis and exacerbations of chronic renal failure.

In my series 10 patients were treated with frusemide, initially $1 \mathrm{~g}$ intravenously and rising gradually to $3 \mathrm{~g}$ over a period of seven days if no response was obtained; a control group of 10 patients were treated conventionally, without frusemide. The patients were allocated to the two groups at random and were evenly matched for age and diagnosis.

I found that in the group treated with frusemide the period of oliguria was shorter and the diuresis was greater than in the controls, so fluid retention was not a problem; there was no life-threatening hyperkalaemia and the patients were discharged earlier (mean seven days). The most practical factor was that in the control group seven patients required peritoneal dialysis, while in the group receiving high-dose frusemide only one patient required peritoneal dialysis.-I am, etc.,

\section{S. KARAYANNOPOULOS}

Renal Unit,

Piraeus General Hospital, Piraeus, Greece

SIR, - I have read with interest the paper by Professor F. Cantarovich and others (24 